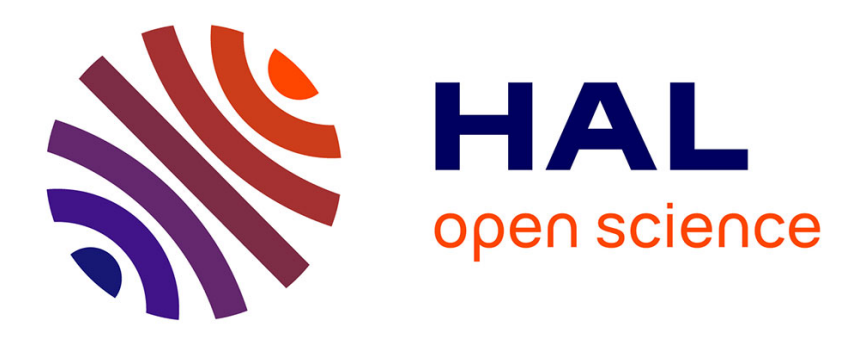

\title{
Ethnic segmentation in marketing: a tool for social domination in France.
}

Sondes Zouaghi

\section{To cite this version:}

Sondes Zouaghi. Ethnic segmentation in marketing: a tool for social domination in France. . Society and Business Review, 2016, Society and Business Review, 10 (3), pp.243-257. 10.1108/SBR-07-20150025 . hal-01359110

\author{
HAL Id: hal-01359110 \\ https://hal.science/hal-01359110
}

Submitted on 1 Sep 2016

HAL is a multi-disciplinary open access archive for the deposit and dissemination of scientific research documents, whether they are published or not. The documents may come from teaching and research institutions in France or abroad, or from public or private research centers.
L'archive ouverte pluridisciplinaire HAL, est destinée au dépôt et à la diffusion de documents scientifiques de niveau recherche, publiés ou non, émanant des établissements d'enseignement et de recherche français ou étrangers, des laboratoires publics ou privés. 


\title{
Ethnic segmentation in marketing: a tool for social domination in France.
}

\author{
Sondes ZOUAGHI \\ Associate Professor \\ Université de Cergy-Pontoise - Laboratoire ThEMA CNRS umr 8184 \\ 33 bd du port - 95011 Cergy-Pontoise \\ sondes.zouaghi@u-cergy.fr \\ +33134256179
}

\begin{abstract}
Purpose - The present article deals with the issue of researchers' responsibility for the dissemination of ideologies which have led to the cultural marginalization and categorization of minority social groups into a dominant/dominated relationship in France. One telling example is the way ethnic segmentation - as now used in marketing - finds its roots in the colonial paradigm.
\end{abstract}

Design/methodology/approach - A critical and analytical review of the literature on ethnic marketing.

Findings - The current paradigm which splits the world into centre and periphery or dominant and dominated, in the French context, is not the only existing one. In the framework of postcolonial studies, researchers in marketing now approach the ethnic market by being as close to consumers as possible and by adapting their methodology to the Consumer Culture Theory.

Originality/value - Some researchers become aware that the feeling of ethnic selfidentification would not exist without the involvement of the dominant group who imposes their view on minorities. As to multicultural individuals, minorities have to adjust to a great variety of social situations by drawing from a set of available cultural identities. It is therefore more a question of multiple selves than ethnic identity. Multicultural individuals create their own identity and co-create new social categories from the grey area between dominant and dominated groups. The postcolonial approach raises the question as to whether ethnicity is a mere ideological construct with no underlying reality but the actual domination of minorities.

Key words: ethnic marketing, segmentation, colonial, postcolonial, consumer culture theory, identity.

Paper type: Conceptual paper. 


\section{Ethnic segmentation in marketing: a tool for social domination in France}

\section{Introduction:}

Ethnicity is a complex and controversial issue. It raises countless questions as to researchers' responsibility when making theoretical choices. Indeed, certain ethnicity theories date back to a colonial socio-political and ideological setting and their dissemination as a result of research has had a profound impact on society. For example, through knowledge derived from the analysis of management practices, researchers in marketing ${ }^{1}$ have effectively contributed to its reification. Once given this stamp of approval, these conceptions of the market are then taken up and amplified by both managers and political decision-makers alike. The aim of the present paper is to demonstrate to researchers how important it is to question the theories and ideological beliefs underpinning their work. In this paper, we will study ethnic segmentation in marketing as a case example.

Postcolonial studies, as a part of the deconstructionist theory school of thought, have allowed us to critically reassess certain marketing practices. For example, ethnic segmentation based on so-called objective criteria is analysed by taking into consideration the colonial paradigms underpinning these criteria. The postcolonial approach allows for a better proximity to the subject so as to understand ethnicity from within. This approach might help develop new methodological tools that could be used in the Consumer Culture Theory (from now on, CCT) framework, in keeping with a de-compartmentalised view of the discipline. The paper proposes to go beyond the qualitative and ethnographic investigative techniques used in CCT today, by using new, effective methods devised by psychiatrists working with migrant patients from various cultures. The inventiveness of these practitioners is similar to that of postcolonial studies.

The paper is divided as follows: the first part presents the socio-political context in which research in ethnic marketing emerged in France; the second part will present the ethnicity theories and underlying paradigms; the third part will discuss the contribution of postcolonial studies to the study of ethnic consumers; and, lastly, the conclusion will weigh up the issue and will propose to branch out to other consumer targets. 1 We use the term "researchers in marketing" to differentiate university researchers or similar from commercial
"market researchers" or "marketing researchers". 


\section{Research in ethnic marketing in France.}

Studies on ethnicity in marketing began in France in 2003, primarily with Hetzel's paper (2003), then with the $\mathrm{ANR}^{2}$ funding of the ETHNOS group in 2005. Prior to this date, ethnicity was not a matter of public debate in France. After a spate of very serious social unrest $^{3}$, the government started taking interest. The emergence of this new topic of study revealed the extent to which research is contextual; researchers are influenced by the sociopolitical and/or ideological situations in which they live and work, or by those of their international predecessors (Renzetti and Lee, 1993). Studying ethnicity in marketing allows us to understand how theories are forged from the predominant paradigms of scholars who, sometimes unwittingly, are the main agents in establishing and disseminating them.

Ethnicity became an object of research in a particular ideological context. For almost half a century the topic was taboo, a fact that could be explained by the interaction of two complementary forces. The first relates to the colonial context in which the term "ethnicity" was born. The concept of ethnicity allowed French colonial authorities to fix ever-shifting realities into set boundaries, thus facilitating census-taking, taxation and labour recruitment. This historical period has neither been sufficiently analysed nor discussed in France. Some historians even consider that the whole colonial narrative is no more than a form of collectively-repressed memories haunted by ghosts and skeletons in the Republic's closet (Ferro, 2003). This "historic thought unthought" may explain the discomfort caused by the very mention of the word ethnicity. Rethinking the history of colonisation requires that we rethink the history of France and its colonised people's. Viewing both perspectives side by side required a decentred approach, which was not seen as a priority before 2005, but which might gradually prove a necessity.

The second origin of the taboo lies in the predominating ideology of French Republican integrationism: "France is one, united and indivisible"4. Between the lines, the concept presupposes an ideal of zero-ethnicity (Grossmann and Miclo, 2002). In the sociological and

2 The mission of the Agence Nationale de la Recherche (national research agency) is to ensure funding of research projects considered a priority for France.

3 In 2005, after the death of two adolescents chased by the police, riots broke out in the French "suburbs". The "suburbs" in question are neighbourhoods composed mainly of immigrant populations and their offspring, the latter belonging to disadvantaged social classes.

4 "la France est une, unie et indivisible" 
political literature, on the other hand, ethnicity is generally used in reference to the social inequalities the ethnic groups are victims of, as well as to a dominant-dominated relationship (Juteau, 1999). And yet "Equality" features in the national motto of France ${ }^{5}$. As a result, a large number of researchers in France consider that the "ethnic" criterion leads to "class manufacture", generating unintentional but quite real discrimination (Payet, 1995; Boubeker, 2003; Wihtol de Wenden, 2003). In this context, one can easily understand why for almost fifty years marketers have not attempted to segment the market according to ethnic differentiation. The French data-protection law "Informatique et Liberte" ${ }^{6}$ does not encourage it either, inasmuch as data that could directly or indirectly reveal respondents' racial or ethnic origins are not allowed to be stored. This legal constraint has led to a vacuum in domestic statistics that makes it difficult to study these targets (Zouaghi, 2012).

Ethnic minorities have cropped up more and more in political and media discourse over the past ten years. This lifting of the taboo has forced managers to pay attention to these groups and to their modes of consumption because of the high commercial potential they represent. Consequently, some research institutes specialise in "Maghrebi" (north-west African) and Afro-Caribbean targets, by-passing the law by asking no questions as to origin but selecting respondents according to name or physical appearance (Zouaghi, 2012). It is therefore partly due to corporate pressure that market researchers began to address the issue.

Most of the earlier studies on the subject originally came from English-speaking countries, particularly the United-States (Özçağlar-Toulouse et al., 2009). American research was conducted at times of growing struggles for rights by Black and then Hispanic minorities. In this context, national homogeneity (as the French view it) was not the issue, but rather minority representation and visibility. Given the scientific vacuum in ethnic marketing in France, researchers studied the English specific streams of literature and some have been inspired by their theories without consciously adopting their underlying vision of the world (Béji-Bécheur et al., 2007, 2008). As a consequence, the vacuum left in social and political thought on ethnic minorities allowed the growth of "ready-made" theories developed abroad. An analysis of the ethnic-marketing literature reveals that few French researchers questioned the paradigms underlying their theoretical framework. Ideas predominating at the time were often experienced on a subconscious level. Segmenting populations according to foreign

\footnotetext{
5 The device, or motto, of the French Republic is Liberté, Égalité, Fraternité, or liberty, equality, fraternity.

6 "Loi Informatique et Liberté" of 6 January 1978, the French data protection and freedom of information law.
} 
origins (down to the third generation or more), to minority religions, or to a particular skin colour, did not lead researchers to think about the origins and consequences of such practices.

The first English-speaking researchers taking an interest in the ethnic question in Marketing belonged to the larger group of socially-dominant culture (Gordon, 1964). They therefore studied it through a dominant-dominated prism. Later, when researchers from minorities, Americans in particular, got involved in the issue, they chose the same underlying paradigm in order to develop a militant research in response to the dominant-group researchers (Franklin, 2014; Albert and Jacobs, 2008; Maldonado and Tansuhaj, 2002; Deshpande et al., 1986; Portes, 1984). The goal was to establish their visibility on the market as economic agents. In France, where such debate did not occur, one must ask the question of researchers' responsibility for the dissemination of certain social and commercial ideological beliefs via their theoretical choices.

\section{Ethnic segmentation: truth-theory or artefact?}

The development of theoretical conceptions of ethnicity raises the question of how the study object is seen, and by whom. Thinking about the nature of boundaries between groups induces researchers in marketing to examine the very meaning of ethnic segmentation.

The first definitions of ethnicity were developed in a positivist framework; they considered belonging to an ethnic group from a collective standpoint, as we can see in earlier works on consumer behaviour (Dussart, 1983). The definitions are based on the postulate according to which within-group behaviours are homogeneous, which leads to an essentialist view of ethnicity (Holland and Gentry, 1999). Confusions are often made between ethnicity and skin colour (Leak, 2014), language spoken (Massey and Mullan, 1984), race (Firestone, 2014), country of origin (Gurak and Fitzpatrick, 1982; Massey, 1981), name (Mirowsky and Ross, 1980), religion (Chuah et al., 2014), etc. This objective, essentialist vision of ethnicity is the one still used today by the vast majority of researchers and research institutes, who thus have the illusion of understanding their market (Zouaghi, 2012). In the United-States, for example, black skin colour is still the variable used to categorize a consumer as belonging to the AfroAmerican sub-culture; in the same way, name or primary spoken language is used for characterising Hispanics. In France, where ethnic statistics are prohibited by the abovementioned "Informatique et Liberté" law, a number of market-research institutes evade the legal issue by choosing to interview only Afro-Caribbean or Maghrebi targets. The lack of 
domestic statistics on these communities prevents assessing how accurate the results are, and the sampling methods are imperfect anyway. Be this as it may, managers continue to commission such research in the hope of matching their products to markets they consider homogeneous (Zouaghi, 2012).

This conception of ethnic groups confines, pins down and classifies consumers according to criteria which do not necessarily reflect their intra-psychic realities but rather the image that the economic and political decision-making majority have of them (Boubeker, 2003). Market analyses where consumer segments are identified according to visible demographic characteristics - such as age or sex - are routine. So it may seem natural to apply the same principle by using visible or easily obtainable ethnic characteristics. However, once consumer segments are defined according to criteria such as origin, skin colour or religion, it also leads to separating members of society based on these very same criteria which then become the bases of economic, political and ideological rhetoric (Béji-Bécheur et al., 2011). Black Africans, for example, do not identify themselves as such, nor do Muslims. Béji-Bécheur et al. (2012) have shown that consumers from minority groups do not define themselves a priori as "ethnic", but end up interiorising the representation of the majority group. Developing theories which reduce individuals to stereotypes will thus inevitably produce or reproduce the tools of social domination. For example, the management practice which consists in increasing the number of separate consumer-good locations supports an ethnicisation of social relations. Putting groups of ethnic products into separate, clearly-identified supermarket aisles creates a feeling of being marginalised. What is emphasised here are the differences between the groups, rather than their similarities. Conversely, organising the store per product group, and integrating products from a variety of cultures in one and the same aisle, would emphasise what brings consumers together rather than what keeps them apart.

During the 1970s, theoretical trends considering ethnicity as a more subjective construct developed alongside the objective view of ethnicity (Chung and Fisher, 1999; Laroche et al., 1998; Deshpande et al., 1986). Adopting a more micro-social approach, these conceptions also made it possible to gradually increase awareness of the individual nature of ethnic experience and the need to develop measures taking the relevant consumers' points of view into account.

Assimilationists suggested measuring the intensity of the bond consumers feels for their culture of origin or host culture on a continuum line ranging from the first to the latter. 
According to this theory, migrant populations leave their culture of origin once and for all and assimilate the host culture (Jun et al., 1993; Laroche et al., 1998). But the model does not take into account the fact that someone may stay attached to their culture of origin or invent another culture which is neither one nor the other (Hui et al., 1992; Wallendorf and Reilly, 1983). The subtext behind the theory is the idea that the dominant culture must be preserved from any influence by the minorities which compose the society. So the assimilationist paradigm posits that sub-cultures will eventually blend harmoniously in with the dominant culture by adopting its codes (Gordon, 1964). French integration is based upon a firm belief in this principle. In terms of marketing, this is expressed by not taking minority consumers into account since they will end up leaving their cultures of origin. While the majority group imposes its vision on minorities in the positivist theory, the assimilationist theory simply ignores them. Time has shown that this vision of minority groups is sometimes wrong. A certain number of migrants stay rooted in their culture of origin, no matter how much time has elapsed.

In an attempt to better reflect the actual experience of migrant peoples, Berry (1980) proposed the acculturation theory. He developed the idea that people of foreign origin do not necessarily move from their culture of origin towards the host culture; they could choose instead any of four possible acculturation strategies (Acculturation, Integration, Separation, Marginalisation). Both Berry, studying minorities in Canada (1980, 1989), and Peñaloza, studying Hispanics in the United-States (1994), leave to subjects the possibility of positioning themselves within an identity strategy at greater or lesser degrees of proximity to both cultures. Mendoza (1989), on the other hand, proposes measuring greater or lesser acculturation along five parameters including language, social affiliations and cultural identifications. The point of these conceptualisations lies in the fact that minorities are not considered as homogeneous groups. These works tends to consider cultures and material expressions (brands, products, etc.) as elements that the individual tactically chooses to construct an acculturation position. Nevertheless, it still confines individuals in one of the four positions without giving them the possibility of navigating between them according to situations.

After a deeper examination of the nature of ethnic groups, Juteau (1999) differentiates two factors which constitute ethnicity: internal and external. The external factor consists of dominant majority-group representations while the internal corresponds more to the way minorities see themselves. The internal factor can only be studied if researchers position 
themselves as close to the object of study as possible. Hence, in Europe, post-assimilationist theory is gaining traction (Askegaard et al., 2005; Lindridge et al., 2004; Oswald, 1999). It studies ethnic experience on the individual and trans-situational level. So the postassimilationist approach resonates with the literature of the 2000s. It shows how individuals who are either immigrants or whose family are immigrants are agents of their own identity tinkering $^{7}$ (Bouchet, 1995) or by navigating between two cultures (Oswald, 1999). Askegaard et al. (2005) consider that members of a minority group create their own identity. Other ethnographic studies in France have shown that ethnicity is an individual, syncretic process (Zouaghi and Béji-Bécheur, 2009, 2011; Béji-Bécheur et al., 2014, 2012). So fixed-identity standpoints do not grasp this intimate, unique and variable bond that individuals share with each culture at their disposal. The point is thus to get beyond the reified vision of host and origin cultures. For post-assimilationists, ethnicity is not a state-defining characteristic but a set of cultural resources. The resources come as much from the culture of origin as the host or even transnational cultures. The individual picks and chooses from the selection available to construct an identity which seems best suited to the situation at hand. For example, a Tunisian English teacher working in Paris could draw respectively from French culture in his interactions with colleagues, Tunisian culture at family events, and English culture when teaching. These cases of multiple identities being very common, researchers have introduced the concept of situational ethnicity (Stayman and Deshpande, 1989). Identification here is not set in stone, but dynamic according to life situation. From this perspective, then, there is no such thing as ethnic identity, but rather multiple selves (Elster, 1995). Post-assimilationist theory re-establishes the notion of free will for people belonging to minority groups, something assimilationist and acculturation theories had put apart.

Post-assimilationnist theory makes us wonder to what extent ethnicity is an artefact existing solely because the dominant culture decided to name it one day. Studying this sensitive subject leads one to realise that the language categories one uses are not neutral: as Sartre (1998) said "naming brings things into existence" ${ }^{\text {. }}$ Those language categories also convey ideological constructs that researchers disseminate in their conceptual choices and the construction of patterns of thought (Béji-Bécheur et al., 2011). They develop the tools and present the results which will be used in subsequent research and management practice.

\footnotetext{
7 “Identity tinkering" refers to Claude Levi-Strauss (1960) concept of "bricolage"

${ }^{8}$ «nommer, c'est faire exister $»$.
} 
The responsibility of researchers in this matter is all the more important since their action may have numerous repercussions. Beyond the social divide it may cause, it creates increasing existential tensions at the individual level. These tensions are experienced when a person becomes aware that the majority group are disparaging the values conveyed by his culture of origin (Laperrière et al., 1992). They are caused by the social asymmetry of power between the culture of origin and the host culture. Hall (1996) demonstrated that identification is a product of the creation of differences from the other, and hence a product of exclusion. For Hall, the internal homogeneity of a group, which is the basis of identity, is not natural. The barriers thus created allow the groups to be "hierarchised" sensu Derrida, making the notions of dominant and dominated cultures become meaningful. The overdetermination of barriers is encouraged by ambient exclusion rhetoric (Korzenny, 2008). The paradigm of cultural domination leads to a greater or lesser sense of identity discontinuity and loss of internal congruence among bicultural individuals belonging to two cultures, of which one excludes the other. Here, ethnicity results in an on-going process revolving around tactics of selfprotection. Sometimes, taking refuge in a protective home-culture matrix, a safe house, proves necessary (Pratt, 1991, 1992) and a process of self-exclusion may thus take hold.

\section{Discussion: towards a postcolonial deconstruction}

The above examination of the theoretical underpinnings of research in ethnic marketing raises the question of the fundamental paradigms upon which such research is based. Insofar as the very concept of ethnicity was developed within a colonial world project (Collignon, 2007), it is accepted that ethnic marketing adopted the same approach, leading to a central/peripheral or dominant/dominated view of markets. Targets considered as ethnic in France consist of migrant groups from former colonies or countries of the so-called South ${ }^{9}$. This explains the use of objective consumer classifications based on origins and hence the assimilationist and acculturation theories. It is legitimate to speak of a colonial paradigm behind these words because "it is indeed a global form of thought going well beyond the political order related to the historic period of colonialism. Its basis is the organisation of the world built in Europe upon a binary opposition of 'them', the Rest, and 'us' Europeans. The opposite manifests itself in a geographic partition, organising the world by continents, dominated intellectually,

\footnotetext{
${ }^{9}$ Italian and English products, for example, are not considered as ethnic.
} 
economically and culturally by Europe, a separate continent." ${ }^{, 10}$ (Collignon, 2007, p.3). So it will come as no surprise that the colonial paradigm issue and its deconstruction is of interest mainly to anthropologists (Appadurai, 2001) and to the literature, following that which founded post-colonial studies, largely English (Saïd, 2003; Fanon, 1952). Their intention was to change the paradigm and write another narrative of the world.

The term "postcolonial" may well be provocative, but the point is not to reverse the dominantdominated relationship nor acknowledge identities which might have been denied (Chakrabarty, 2000). The point is to deconstruct the colonial paradigm and offer a new vision of the world. Postcolonial studies have broadened out and they are now part of a critical approach addressing every discipline. The prefix "post" no longer means "after" but "beyond". The point is thus to invest a discipline from within, open it up and unframe it. Researches, whose methodological cutting edge was decentring, were not taken seriously in France due to the idealism of Republican integration within its homogeneous whole of dominant thought. Still, it derived its inspiration from the French postmodernist movements, from Foucault's French Theory (1966), and Derrida's deconstructionism ${ }^{11}$. The debate actually began in France in 2005 , although not in the most serene political context ${ }^{12}$. In the United-States and India, postcolonial studies have become part of new, contemporary research fields and have acquired worldwide scope through transcolonial studies (Lionnet, 1989; Thomas, 2013). More recently, we are observing a gradual shift from the question of intra-territorial domination towards that of globalised circulation, and both are gradually integrating the scope of globalisation studies.

Ethnic segmentation in marketing would benefit from being examined from this deconstructionist perspective. To create homogeneous market segments, managers interview consumers about their attitudes, opinions and behaviours. The theoretical evolutions in ethnicity encourage researchers to slowly abandon objective attributions and adopt a selfidentifying approach from consumers. This more subjective approach takes interior realities into account but still poses problems. It does not resolve the issue of how to select the study

\footnotetext{
${ }^{10}$ «....il s'agit bien d'une forme globale de la pensée qui dépasse largement l'ordre politique lié à la période historique du colonialisme. Son fondement est cet ordonnancement du monde construit en Europe sur une opposition binaire entre " eux», les Autres, et «nous», les Européens. L'opposition est matérialisée par une partition géographique qui organise le monde en continents, dominés intellectuellement, économiquement et culturellement par l'Europe, continent à part».

11 Cited by John Sallis (1987), Deconstruction and Philosophy: The Texts of Jacques Derrida, University of Chicago Press, Chicago.

12 The above-mentioned 2005 "suburb" riots.
} 
sample. It is hard to explain that you're speaking to someone because they "look ethnic" and then ask questions about their cultural experience and consumption behaviours. This is tantamount to using visible, objective criteria to select the interviewee, once again associated with the stigmatisation they may already have fallen victim to, or labels which they reject.

To avoid this, it is necessary to know beforehand how individuals from this group consider themselves, otherwise the question should be asked at the start of the interview or questionnaire (acting as a screener). But the findings of Béji-Bécheur et al. (2012) warn researchers against such practices. They examined the feeling of ethnic belonging using an introspective approach and show that being aware of belonging to an ethnic group only emerges in social interactions with the host culture group.

Somebody who is bicultural never defines themselves straight off as ethnic. It is the dominant group which does so and, gradually, they integrate the definition themselves. For Juteau (1999), it is exclusion which leads minorities to create an "us" by finding certain traits specifying them within the cultural repertoire. In the case of Béji-Bécheur et al. (2012), there was no pre-existent sensation of exclusion and yet the feeling of a "contrived us"13 was caused because some members of the dominant group labelled them with this presumed ethnic identity. Consequently, asking respondents to self-identify with predefined social categories (ethnic group, race, culture, etc.) eventually means making them interiorize barriers and trigger or even encourage oppositions (Lavaud and Lestage, 2005). We end up with the same pitfall as before (essentialism, stigmatization, etc.). This then leads us to examine the very notion of ethnic segmentation, which would seem incompatible with that of free will and the universal nature of principles proper to humanist ideology.

Being aware of the effects of ethnic segmentation on the reproduction of domination ideologies has led certain researchers to wonder how to avoid this external vision cast upon people who share several cultures. Post-assimilationists thus adopted a methodology enabling them to study the dynamics of identity experience as closely to consumers as possible. According to this theoretical approach, called Consumer Culture Theory (CCT) (Arnould and Thompson, 2005), a consumption object is a cultural resource like any other which expresses an identity matching a given situation. Askegaard et al. (2005) showed how Greenlanders (Inuit) in Denmark sometimes experience their consumption as a badge of identity, sometimes as a means to avoid misunderstandings with the dominant group and sometimes as a means to

13 "Nous forcé", lit. a "forced us" 
access a globalized transnational culture. Zouaghi and Béji-Bécheur (2011) show how women of Tunisian origin, when using body care products, manifest their intention of expressing very different identities ${ }^{14}$ within one consumption episode and how they navigate between these intentions. Béji-Bécheur et al. (2014) show how consumers seek a variety of cultural expression in their consumption of couscous according to not only culture but also the various moments of consumption (with family, friends, at a party, among colleagues, etc.).

Research based on CCT highlights the polymorphic character of consumption. The next point is thus to deconstruct conventional marketing rhetoric in which a product represents a set of characteristics corresponding to a well-identified consumer group expressing homogeneous expectations. It seems that consumption objects are means of navigating between cultures and expressing different traits of oneself. These situations, where the subjects define their attitude and devise a strategy of the self are one of the new objects of post-colonial studies (Bhabha, 2007). Movement thus becomes one of the key concepts of postcolonial analysis. Multicultural consumers fit inside the gaps between the various identities to create new social facts. Zouaghi and Béji-Bécheur (2009) show that certain Maghrebi migrants adopt modes of consumption from sub-Saharan Africa and vice-versa (bodily hygiene products, for example). In the French "suburbs", immigrants of various origins mingle, communicate and develop specific codes of consumption straddling several cultures. They thus create new identitybased positions resulting from a creolization process.

Studies about the movements of cultural navigation show that, contrary to Hall's theories (1996) - which predict the protection and closing of cultural frontiers- identity can assert itself by attributing a certain value to the other and by being open to its specificity. Ben Alaya and Romdhane (2006) show how Tunisians attribute the French with positive qualities, and Zouaghi and Béji-Bécheur (2011) show that under certain situations Tunisian women in France integrate the dominant cultural references positively in order to highlight their own culture of origin in the eyes of the majority, shaping their discourse by using the dominant culture's codes. This process of cultural interpenetration leads to peaceful identity-building. Today, as we see some groups shutting themselves out, there is a urgent need for cultural rebalancing. Zouaghi and Béji-Bécheur (2011) studied the experience of identity in the

14 The identity intentions noted are: 1 . Conserving and ascribing value to the identity by presenting it to the host culture; 2. Identity adaptation and cultural flexibility; 3. Standing up for one's culture and brushing aside certain aspects of the host culture; 4. Assimilation and rejection of certain aspects of the original culture. 
hammam $^{15}$, which represents an ethnic enclave in France where the cultural domination relationship is reversed. This reversed zone of contact allows relations between the two cultures to be re-balanced and helps to soothe the existential tensions of minorities, as the process of opening up to the other takes place in a peaceful and constructive context.

The postcolonial deconstruction of ethnic marketing was made possible thanks to a specific methodology. Its goal is to be as close as possible to the consumers - the CCT epistemology being based upon the idea that knowledge cannot be approached from an external, objective point of view, but from the researcher's actually experiencing it as a co-participant (ÖzçağlarToulouse and Cova, 2010). The methodological tools used for ethnic studies are characterized by an ever-increasing number of mainly (but not exclusively) qualitative and ethnographic approaches. The basic method is interviews, but introspection may at times prove necessary (Béji-Bécheur et al., 2012). The itinerary method (Desjeux, 2006) and ethnographic immersion combining respondents' observation and life-stories (Peñaloza, 1994) are also used. Log-books, photographs or filmed observations and various other media are now valuable additions to the mere transcripts of the interview.

Ethno-psychologists working on migrant populations also recommend using a wide range of data collection methods. They suggest setting up an eclectic, complementary system designed to tailor the methodological framework to each situation (Moro et al., 2006). Principles from systems analysis, linguistics, ethnology and psychoanalysis are used to varying degrees. LéviStrauss (1960) favoured this form of theoretical and methodological versatility, calling it "methodological tinkering". However, it is paramount that this eclectic system be centred theoretically upon a stable frame of reference (sociology, psychology, etc.). The more creative the methodology, the deeper and firmer its roots in theory must be.

The reason for this methodological multiplicity is to be sought in the need for decentring and still not formalized - adaptability to the studied cultures. For decades, studies on populations of minority cultures were conducted according to the same scientific canons as studies on westerners. However, certain psychologist-anthropologists and ethno-psychologists (Dereveux, 1972; Nathan, 1986), observing the failure of certain conventional protocols, encouraged researchers to question their methods all the way down to the scientific methods' basic postulates. In this respect, the fundamental postulate of any qualitative or quantitative study based on respondent declaration is that the interviewee wishes to reveal the reality of

15 Steam room, translated ironically as Turkish bath in English. 
their thought. Otherwise, the scientific quality of most social-science methodologies could be questioned. But the postulate turns out to be false under certain cultural conditions. For example, in the African culture, the respondent feels that the interviewer is in a position of power because, unlike them, they know the object of the study. Being in a position of power, the interviewer becomes potentially dangerous to the respondent (Réal and Moro, 2006). Here, the latter seeks protection by supplying deliberately wrong or vague answers.

The question was first raised by psychiatrists responsible for treating migrant patients. Ethnopsychiatrists tried to gradually modify the therapeutic protocols. They tested a certain number of them and ended up with a new clinical interview protocol where patients would present themselves accompanied by friends and family acting in a protective capacity (Nathan, 1986). The methodological deconstruction performed by heterodox ethno-psychiatrists made it possible, while being as close as possible to migrant patients, to devise new, effective methodologies. Since marketing has taken most of these methodologies from psychology, sociology or ethnology, it is important to integrate thinking from these disciplines and come up with new methodologies that respect the modi operandi of people from other cultures.

The postcolonial approach allows us thus to examine the notion of ethnic segmentation and the investigation techniques used to categorize its consumers. Research done from this perspective demonstrates that the closer researchers get to their object of study (the individual), the more the idea of ethnicity disappears, leaving only diversity of the experienced social role.

\section{Conclusion and research perspectives}

Based upon an analysis of research in ethnic marketing and segmentation practices, the present article addressed the question of researcher responsibility for the dissemination of ideologies which have led to the marginalisation and cultural confinement of social groups in a dominant/dominated relationship. Researchers in business science consider themselves close to management issues, but are also one of the primary links between their researches and social sciences, psychology, ethnology, and political science. Their role is not merely to take into account the demands for corporate profitability but also to accept responsibility towards society as representative of the paradigms behind ideologies. 
Researchers in marketing analyse management practices and previous theories embedded in given socio-political and ideological contexts. Then, by creating their own model, they create structured knowledge which becomes, de facto, a commonly-held truth. The structured knowledge acquires legitimacy for having originated in research. It is then taken up by managers and public agents whom in turn disseminate it as truth. This reiterated confirmation of dominant thought often occurs without its agents being really aware of the underlying stakes.

Detailed study of ethnic segments, theories and methods lets us understand that at the root of this market interpretation is the colonial paradigm. And this paradigm separating the world into centre and periphery or dominant and dominated is not the only one existing. Postcolonial studies propose to deconstruct the disciplines from within to offer a new vision of the world. They represent an abundant source of inspiration for researchers in marketing wanting to tackle ethnic markets with the greatest possible degree of proximity to consumers. The methodologies adapted to the CCT make it possible to investigate individual experience in depth. This theoretical positioning makes the studied individual worthy of interest for their own sake. They become another me. So researchers become aware that ethnic feeling does not exist without the dominant group imposing this way of thinking on minorities. Multicultural people cope with a range of social situations drawing from various available ingredients of identity. It is hence more a question of multiple selves than ethnic identity. They create their own identity and co-create new social categories out of the no-man's lands between dominant and dominated groups.

The postcolonial approach raises the question as to whether ethnicity is a mere ideological construct, with no underlying reality behind it, only reflecting a top-down vision of minorities. Interestingly, neither foreigners from other Western countries nor minorities in France (Alsatians, Britons, etc.) are referred to in terms of ethnicity. "Ethnicity" therefore is a clear reference to the colonial past and to the cultural and economic domination of other people. Researchers should bear this in mind when tackling the question of ethnic marketing. "Multiple identities" or "identity marketing", on the other hand, refer to the great variety of cultures that are available without tying oneself up to a colonial vision of consumers.

Deconstructing ethnic segmentation can be extended to include other topics in marketing. It would also be interesting, for example, to examine gender or social class. Post-modern research effectively criticised these two segments for confining consumers into a rigid status. 
The very notion of segmentation which lies at the base of marketing strategy can also be examined in the light of this analysis.

\section{References}

Albert, T.C. and Jacobs, R.D. (2008), "Television Attitudes and TV Types of AfricanAmericans, Latinos, and Caucasians", Journal of Advertising Research, Vol. 48 No. 2, pp. 235-246.

Appadurai, A. (2001), Après le colonialisme. Les Conséquences culturelles de la globalisation, Payot, Paris.

Arnould, E.J. and Thompson, C.J. (2005), "Consumer culture theory (CCT): twenty years of research", Journal of Consumer Research, vol. 31 No. 4, pp. 868-882.

Askegaard, S., Arnould, E.J. and Kjeldgaard, D. (2005), "Postassimilationist ethnic consumer research: qualifications and extensions", Journal of Consumer Research, Vol. 32, pp. 160170.

Beji-Becheur, A., Jamel, A., Özçağlar-Toulouse, N. and Zouaghi S. (2008), "Ethnicity and Consumption in Europe: Comparing and Contrasting France and the UK", in European Advances in Consumer Research, Borghini, S., McGrath, M.A. and Otnes, C.C. (Eds.), pp.283-284.

Béji-Bécheur, A., Ourahmoune, N. and Özçağlar-Toulouse, N. (2014), "The polysemic meanings of couscous consumption in France", Journal of Consumer Behaviour, Vol. 13, pp. 196-203.

Béji-Bécheur, A., Özçağlar-Toulouse, N. and Herbert, M. (2011), "Étudier l'ethnique, La construction de la responsabilité des chercheurs face à un sujet sensible", Revue française de gestion, Vol. 7 No. 216, pp. 111-128.

Béji-Bécheur, A., Özçağlar-Toulouse, N. and Zouaghi, S. (2007), "Ethnicity, acculturation, and consumption in France", paper presented at the 34th Lalonde Conference, Marketing, communication and consumer behavior , 5-8 june 2007, Lalonde les Maures, France, available at: http://www.lalondeconference.org/CB/2007 lalonde seminar/N11.pdf (accessed 20 April 2015).

Béji-Bécheur, A., Özçağlar-Toulouse, N. and Zouaghi, S. (2012), "Introspected Ethnicity: Researchers in Search of their Identity", Journal of Business Research, Vol. 65 No. 4, pp. 504-510.

Ben Alaya, D. and Romdhane, N. (2006), "Contexte d'actualisation de l'auto-définition et assimilation/différenciation par rapport aux catégories groupales", Muqabaçat Intersignes, Vol. 1, pp. 184-214.

Berry, J.W. (1980), "Acculturation as varieties of adaptation", in Padilla, A.M. (Ed.) Acculturation: Theory, models, and some new findings, Boulder, Westview, pp. 9-25. 
Berry, J.W. (1989), “Acculturation et adaptation psychologique”, in Retschitzki, J., BosselLagos, M. and. Dasen P.R (Eds.), La recherche interculturelle, L'Harmattan, Paris, pp. 135145.

Bhabha, H.K. (2007), les lieux de la culture : une théorie postcoloniale, Payot, [1994], Paris.

Boubeker, A. (2003), "Ethnicité relation inter ethnique ou ethnicisation des relations sociales, les champs de la recherche en France”, Ville-Ecole-Intégration, Vol. 135, pp. 40-50.

Bouchet, D. (1995), "Marketing and the redefinition of ethnicity", in Costa, J.A. et Bamossy, G.J., (Eds.), Marketing in a multicultural world: Ethnicity, nationalism and cultural identity, CA: Sage, Thousand Oaks, pp. 68-104.

Chakrabarty, D. (2000), Provincializing Europe: Postcolonial thought and historical difference, Princeton University Press, Princeton.

Chuah, SH., Hoffmann, R., Ramasamy, B. and Tan, J.H.W. (2014), "Religion, ethnicity and cooperation: An experimental study", Journal of Economic Psychology, Vol. 45 No. 4, , pp. $33-43$.

Chung, E. and Fischer, E. (1999), "It's who you know: intracultural differences in ethnic product consumption”, Journal of Consumer Marketing, Vol. 16 No. 5, pp.482-501.

Collignon, B. (2007), "Note sur le fondement des postcolonial Studies", EchoGéo, Vol. 1, available at: URL: //echogeo.revues.org/2089; DOI : 10.4000/echogeo.2089 (accessed 5 march 2015).

Dereveux, G. (1972), Ethnopsychanalyse complémentariste, Flammarion, Paris.

Deshpande, R., Hoyer, W.D. and Donthu, N. (1986), "The intensity of ethnic affiliation: a study of the sociology of hispanic consumption", Journal of Consumer Research, Vol. 13, pp. 214-220.

Desjeux, D. (2006), La consommation, Collection Que sais-je ?, PUF, Paris.

Dussart, C. (1983), Comportement du consommateur et stratégie de marketing, Mc GrawHill, Book Company, New York.

Elster, J. (1995), The multiple self, Cambridge University Press, Cambridge.

Fanon, F. (1952), Peau noire, masques blancs, Seuil, Paris.

Ferro, M. (2003), Livre noir du colonialisme. XVIe-XXIe siècle : de l'extermination à la repentance, Robert Laffont, Paris.

Firestone, S. (2014), "Race, Ethnicity, and Credit Card Marketing", Journal of Money, Credit \& Banking (Wiley-Blackwell), Vol. 46 No. 6, p. 1205-1224.

Foucault, M. (1966), Les mots et les choses (une archéologie des sciences humaines), Gallimard, Paris.

Franklin, E.E.T. (2014), “Are You Reaching The Black-American Consumer?”, Journal of Advertising Research. Vol. 54 No. 3, pp. 259-262. 
Grossmann, R. and Miclo, F. (2002), La République minoritaire : contre le communautarisme, Michalon, Paris.

Gurak, D.T. and Fitzpatrick, J.P. (1982), "Intermarriage among Hispanic Ethnic Groups in New York City", American Journal of Sociology, Vol. 87 No.1, pp. 921-934.

Hall, S. (1996), “Introduction: who needs Identity?", in Hall, S. et du Gay, P (Eds.), Question of cultural Identity, Sage, London, pp. 1-17.

Hetzel, P. (2003), "Pratiques et Tabous du Marketing : Segmenter par les Critères Ethniques et Communautaires", Décisions Marketing, Vol. 32, pp. 97-103.

Holland, J. and Gentry, J.W. (1999), "Ethnic consumer reaction to targeted marketing: a theory of intercultural accommodation", Journal of Advertising, Vol. 28, pp.65-77.

Hui, M.K., Joy, A., Kim, C. and Laroche, M. (1992), "Acculturation as a determinant of consumer behaviour", in conceptual and methodological issues, American Marketing Association winter Educators' conference: Marketing theory and applications, 1992, American Marketing Association, Vol. 3, pp. 466-473.

Jun, S., Ball, A.D. and Gentry, J.W. (1993), "Modes of consumer acculturation", in Advances in Consumer Research, Mc Alister, L. and Rothschild, M.L. (Eds.), Association for Consumer Research, Vol. 20, Provo, UT, pp. 76-82.

Juteau, D. (1999), l'éthnicité et ses frontières, Presse de l'Université de Montréal, 1999).

Korzenny, F. (2008), "Multicultural Marketing and the Reasons Why", Journal of Advertising Research, Vol. 48 No. 2, pp. 173-176.

Laperrière, A., Compère, L., D’Khissy, M., Dolce, R., Fleurant, N. and Vendette, M. (1992), "Relations ethniques et tensions identitaires en contexte pluriculturel", Santé mentale au Québec, Vol. XVII No. 2, pp. 133-156.

Laroche, M., Kim, C. and Tomiuk, M.A. (1998), "Italian ethnic identity and its relative impact on the consumption of convenience and traditional foods", Journal of Consumer Marketing, Vol. 15 No. 2, pp. 121-151.

Lavaud, J-P. and Lestage, F. (2005), “Compter les Indiens: Bolivie, Etats-Unis, Mexique”, L’année sociologique, Vol. 55, No. 2, pp. 487-520.

Leak, R.L. (2014), "Situational effects of ethnic phenotype in marketing: investigating interand intra-ethnic preferences for minorities in advertisements", Academy of Marketing Studies Journal, Vol. 18 No. 2, pp. 135-147.

Levi-Strauss C. (1960), La pensée sauvage, Plon, Paris.

Lindridge, A.M., Hogg, M.K. and Shah M. (2004), "Imagined multiples worlds: How south Asian women in Britain use family and friends to navigate the "broeader crossing" between household and societal contexts", Consumption, Market and Culture, Vol. 7 No.3, pp.211238.

Lionnet F. (1989), Autobiographical Voices: Race, Gender, Self-Portraiture, Cornell University Press, Ithaca. 
Maldonado, R., and Tansuhaj, P. (2002), “Segmenting a local latino market using Berry's acculturation taxonomy", Advances in consumer research, Vol. 29 No. 1, pp. 414-420.

Massey, D.S. (1981), "Social Class and Ethnic Segregation", American Sociological Review, Vol. 46 No.5, pp. 641-650.

Massey, D.S. and Mullan, B.P. (1984), "Processes of Hispanic and Black Spatial Assimilation", American Journal of Sociology, Vol. 89 No. 1, pp. 836-873.

Mendoza, R.H. (1989), "An empirical scale to measure type and degree of acculturation in mexican-american adolescents and adults", Journal of Cross-Cultural Psychology, Vol. 20, pp. 372-385.

Mirowsky, J. and Ross, C.E. (1980), "Minority Status. Ethnic Culture, and Distress: A Comparison of Blacks, Whites, Mexicans, and Mexican Americans", American Journal of Sociology, Vol.86 No. 3, pp. 479-495.

Moro, M-R., De la Noë, Q. and Mouchenik, Y. (2006), Manuel de psychiatrie transculturelle, La pensée sauvage, Grenoble.

Nathan, T. (1986), La folie des autres. Traité d'ethnopsychiatrie clinique, Dunod, Paris.

Oswald, L.R. (1999), "Cultural swapping: consumption and the ethnogenesis of middle-class haitian immigrants", Journal of Consumer Research, Vol. 25, pp. 303-318.

Özçağlar-Toulouse, N. and Cova, B. (2010), “A History of French CCT: Pathways and Key Concepts”, Recherche et Applications en Marketing, Vol. 25 No. 2, pp. 69-91.

Özçağlar-Toulouse, N., Béji-Bécheur, A., Fosse-Gomez, M-H., Herbert, M. and Zouaghi, S. (2009), "Ethnicity in the Study of the Consumer: an Overview", Recherche et Applications en Marketing, Vol. 24 No. 4, pp. 57-76.

Payet, J-P. (1995), Collèges de banlieue. Ethnographie d'un monde scolaire, Méridiens Klinsieck, Paris.

Peñaloza, L. (1994), "Atraversando frontieras/Border crossing: A critical ethnographic exploration of the consumer acculturation of Mexican immigrants", Journal of Consumer Research, Vol. 21 No.1, pp. 32-54.

Portes, A. (1984), "The Rise of Ethnicity: Determinants of Ethnic Perceptions Among Cuban Exiles in Miami", American Sociological Review, Vol. 9 No. 3, pp. 383- 397.

Pratt, M.L. (1991), “Arts of the Contact Zone”, Profession, Vol. 91, pp. 33-40.

Pratt, M.L. (1992), Imperial Eyes: Travel Writing and Transculturation, Routledge. London/New York.

Réal, I. and Moro, M-R. (2006), "La consultation transculturelle d'Avicenne (Bobigny, France)", in Moro, M-R, De la Noë, Q. and Mouchenik, Y (Eds.), Manuel de psychiatrie transculturelle, La pensée sauvage, Grenoble.

Renzetti C.M. and Lee R.M. (1993), Researching Sensitive Topics, Sage, Thousand Oaks, CA. 
Saïd, E.W. (2003), L'Orientalisme. L'Orient créé par l'Occident, Seuil, [1978], Paris.

Sartre, J-P. (2008), La responsabilité de l'écrivain, Verdier, [1946], Paris,

Stayman, D.M. and Deshpande, R. (1989), "Situational ethnicity and consumer behavior", Journal of Consumer Research, Vol.16, pp. 361-371.

Thomas D. (2013), Africa and France: Postcolonial Cultures, Migration, and Racism, Indiana University Press, Bloomington.

Wallendorf, M. and Reilly, M.D. (1983), "Ethnic migration, assimilation, and consumption", Journal of Consumer Research, 10: 292-302.

Wihtol de Wenden, C. (2003), "Discrimination ethnique. Panorama des dispositifs existant en France", Ville-Ecole-Intégration, Vol. 135.

Zouaghi, S. (2012), "Etudier l'ethnicité : un défi et des solutions innovantes", in BéjiBécheur, A. and Özçağlar-Toulouse, N. (Eds), L'Ethnicité : Fabrique Marketing, Edition EMS Management et Société, Paris, pp. 75-105.

Zouaghi, S. and Béji-Bécheur, A. (2009), "Soins de beauté pour dire son ethnicité", 14ème Journée de Recherche en Marketing de Bourgogne, novembre 2009, Dijon, France, available at: $\quad$ http://leg2.u-bourgogne.fr/CERMAB/z-outils/documents/actesJRMB/JRMB142009/Zouaghi-Becheur.pdf (accessed 20 April 2015).

Zouaghi, S. and Béji-Bécheur, A. (2011), "Hammam, soins du corps et soins de soi : Espace ethnique et réduction des tensions identitaires", Perspectives Culturelles de la Consommation, Vol. 1 No. 1, pp. 79-108. 